\title{
SOSIALISASI FORMULASI PENYESUAIAN TARIF DAN PENERAPANNYA BAGI PEMEGANG KUASA USAHA KETENAGALISTRIKAN (PKUK)
}

\section{Socialization Of Rate Adjustment Formulation And Its Implementation For Electricity Business Authority Holders (PKUK)}

\author{
Muhammad Mujahidin ${ }^{1 *}$, Firmansyah Kusasi ${ }^{2}$ \\ ${ }^{1)}$ Jurusan Teknik Elektro, Fakultas Teknik, Universitas Maritim Raja Ali Haji, Tanjungpinang \\ 2)Jurusan Manajemen, Fakultas Ekonomi, Universitas Maritim Raja Ali Haji, Tanjungpinang \\ *Korespondensi : mujahidin@umrah.ac.id
}

\begin{abstract}
ABSTRAK
Listrik merupakan salah satu komoditi strategis dalam perekonomian Indonesia karena selain digunakan secara luas oleh masyarakat terutama untuk keperluan penerangan, listrik juga merupakan salah satu sumber energi utama bagi sektor industri. Oleh karena itu, Pemerintah menaruh perhatian yang cukup besar terhadap harga penjualan listrik kepada konsumen, mengingat perubahan harga. listrik akan mempunyai dampak yang cukup signifikan terhadap kenaikan harga-harga umum, yang pada gilirannya akan berpengaruh juga terhadap perekonomian secara makro. Salah satu faktor yang menentukan tingkat harga penjualan listrik adalah biaya penyediaan tenaga listrik, pertumbuhan listrik di Indonesia cukup tinggi dan rasio elektrifikasi masih rendah atau masih banyak daerah yang belum mendapat aliran listrik maka perlu pendanaan yang cukup besar yang akan dipergunakan untuk mempertahankan suplai listrik di masyarakat dan menambah usaha melistriki daerah yang belum mendapatkan listrik, metodologi teknis yang diterapkan, mobilisasi \& konsolidasi tim, penyusunan rencana kegiatan serta pengumpulan data referensi. Capaian/target, mengetahui komponen-komponen biaya yang mempengaruhi besaran tarif tenaga listrik, membuat suatu Kajian Formulasi Penyesuaian dan Penerapannya bagi Pemegang Kuasa Usaha Ketenagalistrikan. Hasil yang diharapkan dari kegiatan ini adalah tersusunnya kajian formulasi penyesuaian tarif dan penerapannya bagi PKUK, Manfaat kegiatan ini adalah sebagai acuan dalam menetapkan kebijakan tarif dan penerapannya bagi PKUK. Sedangkan dampak dari kegiatan ini adalah terselenggaranya usaha penyediaan tenaga listrik oleh PKUK, Sebagai tindak-lanjut terhadap Kerangka Acuan Kerja pekerjaan Kajian Formulasi Penyesuaian Tarif dan Penerapannya Bagi Pemegang Kuasa Usaha Ketenagalistrikan (PKUK) yang diselenggarakan oleh Departeman Energi dan Sumber Daya Mineral c.q Direktorat Jenderal Listrik dan Pemanfaatan Energi.
\end{abstract}

Kata kunci : PKUK, Elektrifikasi

\begin{abstract}
Electricity is one of the strategic commodities in the Indonesian economy because apart from being widely used by the public, especially for lighting purposes. Electricity is also one of the main sources of energy for the industrial sector. Therefore, the government pays considerable attention to the selling price of electricity to consumers, given the price changes. Electricity will have a significant impact on the increase in general prices, which in turn will also affect the macro economy. One of the factors that determine the selling price of electricity is the cost
\end{abstract}


of providing electricity, the growth of electricity in Indonesia is quite high and the electrification ratio is still low or there are still many areas that have not received electricity. Adding electricity to areas that have not yet received electricity, applied technical methodologies, team mobilization \& consolidation, preparation of activity plans and collection of reference data. Achievements/targets, knowing the cost components that affect the amount of electricity tariffs, making a study of the adjustment formulation and its application for the holder of the electricity business authorization (PKUK). The expected result of this activity is the compilation of a study of the tariff adjustment formulation and its application for PKUK. The benefits of this activity are as a reference in setting tariff policies and their application for PKUK. Meanwhile, the impact of this activity is the implementation of the electricity supply business by PKUK, as a follow-up to the terms of references for the study of tariff adjustment formulation and its application for the holders of the electricity business authorization (PKUK) organized by the Ministry of Energy and Mineral Resources cq the Directorate General of Electricity and Energy Utilization.

Keyword : PKUK, electrification

\section{PENDAHULUAN}

Sejumlah permasalahan diteliti untuk mendapatkan Penyediaan tenaga listrik dapat berlangsung dengan baik apabila tersedia dana investasi baru dari pihak lain atau penyedia listrik telah memperoleh laba (margin) yang dapat dipergunakan untuk investasi. Suatu perusahaan penyedia listrik memperoleh laba yang berarti penyedia listrik tersebut dapat memberikan sebagian keuntungan untuk investasi. Dengan demikian penyedia tenaga listrik dapat bertahan (sustainable), tanpa bantuan pemerintah untuk investasi.

\section{METODE}

\section{Metode Pengumpulan Data}

Metode pengumpulan data adalah dengan tahapan yang akan dilakukan untuk penyelesaian pekerjaan adalah sebagai berikut :

a. Tahap Persiapan pada tahap persiapan dilakukan langkah-langkah sebagai berikut:

1. Mobilisasi \& Konsolidasi Tim Tahap untuk pembagian dan pengkoordinasian tugas setiap anggota tim.
2. Penyusunan Rencana Kegiatan Tahap untuk perencanaan hal-hal yang akan dilakukan secara mendetail sesuai dengan urutan waktunya.

3. Pengumpulan Data Referensi Merupakan tahap untuk pengumpulan data-data yang digunakan sebagai landasan awal dalam pengkajian.

b. Tahap Studi Literatur, merupakan tahap pengumpulan dan pembelajaran akan teori-teori yang berhubungan dengan subsidi dan tarif listrik.

c. Tahap Penyusunan Laporan Pendahuluan, merupakan tahap untuk menyusu laporan awal sebagai gambaran umum akan setiap hal yang akan dilakukan dalam pengkajian kali ini.

d. Tahap Pelaksanaan, merupakan tahap pelaksanaan pekerjaan sesuai dengan rancangan awal yang telah dibuat.

e. Tahap Penyelesaiaan Pekerjaan, merupakan tahap akhir dari setiap pekerjaan yang telah dilakukan yaitu penyusunan laporan akhir dari setiap kegiatan dan pemberian hasil pengkajian disertai dengan solusi.

f. Tahapan pekerjaan Kajian Formulasi Penyesuaian Tarif dan Penerapannya bagi Pemegang Kuasa Usaha Ketenagalistrikan (PKUK) telah 
memasuki tahap persiapan dan studi literatur.

\section{Perancangan Sistem}

Perancangan sistem yang meliputi diagram kerangka pikir pekerjaan disajikan pada Gambar 1., biaya penyediaan tenaga listrik disajikan pada Gambar 2., dan bagan struktur biaya penyediaan tenaga listrik disajikan pada Gamabr 3. seluruhnya berdekatan dengan jaringan PLN. disamping itu, ada sejumlah 85 perusahaan yang merupakan pelanggan PLN tetapi memiliki captive power, seluruhnya berjenis diesel dengan kapasitas total captive power adalah 45,23 MW, dari 10 perusahaan yang disurvei di Kabupaten Bintan, terdapat 2 perusahaan yang bersedia menjual excess power-nya kepada PLN. Perusahaan tersebut bersedia menjual captive power-nya ke PLN

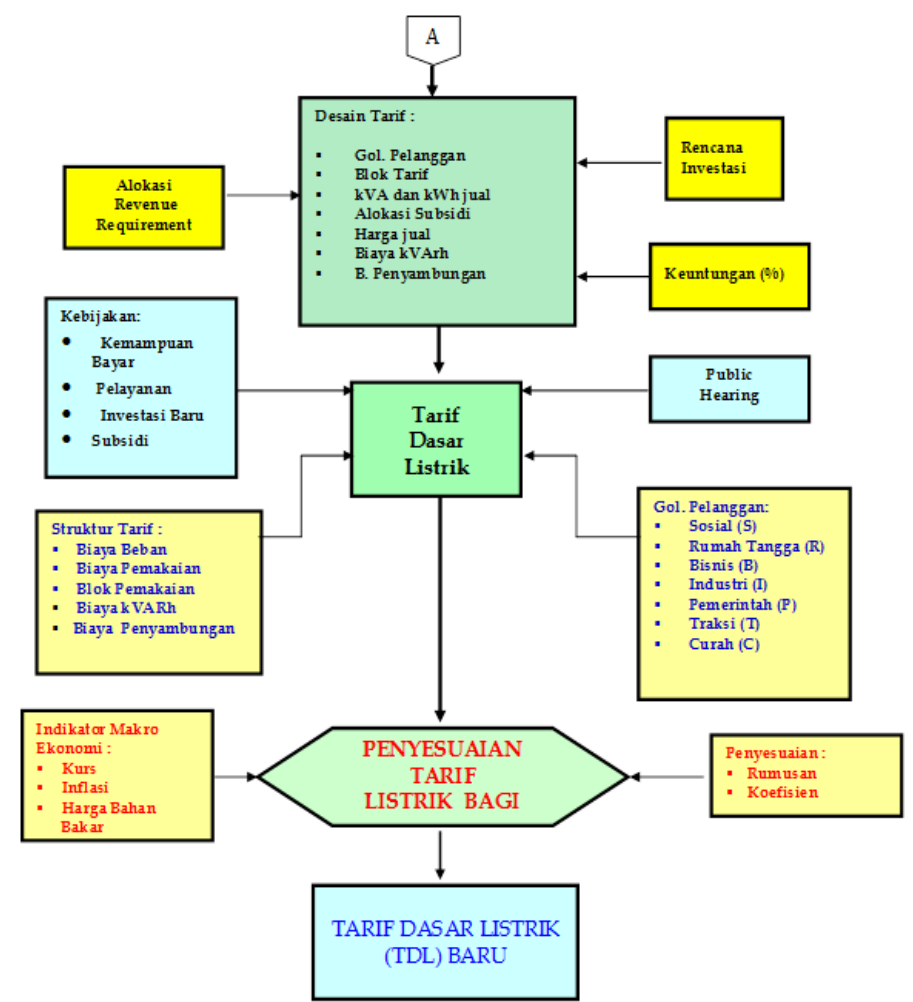

Gambar 1. Diagram kerangka pikir pekerjaan

Analisis kerangka pikir digunakan untuk menggambarkan bagaimana sistem akan dibangun, penerapan Allowable Cost industry listrik sebagai parameter penentuan pembiayaan yang effisien.

Meskipun luas Kabupaten Bintan tidak terlalu besar tetapi populasi industrinya cukup besar dan dari data yang diperoleh PLN terdapat 190 perusahaan yang menggunakan listrik sendiri dengan total captive power sebesar $616.323 \mathrm{kVA}$ secara berulang hingga memenuhi kriteria berhenti. Terdapat 27 perusahaan yang memiliki captive murni berkapasitas 204,614 MW, sebagian besar berjenis usaha pengolahan hasil industri manufaktur, dan hampir dengan syarat PLN bersedia menanggung seluruh instalasi tambahan yang sekiranya akan diperlukan. Perusahaan tersebut juga menginginkan persyaratan-persyaratan antara lain: pemakaian daya maksimal, pembayaran tepat waktu, maintenance dan service ditangani oleh PLN. dari informasi beban, dapat dilihat bahwa daya pembangkit yang dimiliki responden masih bersifat cadangan dan belum mencukupi kebutuhan sendiri. Perusahaan tersebut bersedia menjual excess power, karena diharapkan energi yang tidak terpakai dapat dimanfaatkan secara efisien. Sedangkan perusahaan-perusahaan yang tidak bersedia menjual excess power menganggap bahwa genset yang tersedia 
hanya cukup sebagai cadangan dari berkapasitas di bawah $500 \mathrm{kVA}$. Lima perusahaan tersebut. responden mempunyai daya pembangkit

\begin{tabular}{|c|c|c|c|c|c|c|c|}
\hline \multirow{2}{*}{$\begin{array}{l}\text { Satuan } \\
\text { PLN/Provinsi }\end{array}$} & \multicolumn{3}{|c|}{$\begin{array}{l}\text { Banyaknya Captive Power } \\
\text { (CP) }\end{array}$} & \multicolumn{3}{|c|}{ Daya Terpasang (kVA) } & \multirow{2}{*}{$\begin{array}{c}\text { KVA PLN } \\
\text { pada CP } \\
\text { Cadangan }\end{array}$} \\
\hline & $\begin{array}{c}\text { CP } \\
\text { Murni }\end{array}$ & $\begin{array}{c}\mathrm{CP} \\
\text { Cadangan }\end{array}$ & Jumlah & CP Murni & $\begin{array}{c}\mathrm{CP} \\
\text { Cadangan }\end{array}$ & Jumlah & \\
\hline $\begin{array}{l}\text { Wilayah } \\
\text { Tanjungpinang } \\
\text { kota }\end{array}$ & 65 & 64 & 129 & $95.498,00$ & $116.575,00$ & $212.073,00$ & $210.265,0 d$ \\
\hline $\begin{array}{l}\text { Tanjungpinang } \\
\text { Barat }\end{array}$ & 63 & 81 & 144 & $244.658,00$ & $54.588,00$ & $299.246,00$ & \\
\hline $\begin{array}{l}\text { Tanjungpinang } \\
\text { Timur }\end{array}$ & 114 & 143 & 257 & $610.943,00$ & $117.145,00$ & $728.088,00$ & \\
\hline PT PLN Bintan & 3 & 33 & 36 & $3.211,60$ & $18.198,50$ & $21.410,10$ & \\
\hline TanjungUban & - & 95 & 95 & - & $131.031,00$ & $131.031,00$ & $46.073,00$ \\
\hline & - & - & - & - & - & - & \\
\hline Teluk Sebong & 71 & 139 & 210 & $749.853,50$ & $103.734,00$ & $853.587,00$ & $99.504,00$ \\
\hline Toapaya & 43 & 140 & 183 & $12.944,00$ & $37.396,00$ & $50.340,00$ & \\
\hline Teluk Sasa & 65 & 246 & 311 & $24.585,00$ & $63.804,00$ & $88.389,00$ & \\
\hline Bintan pesisir & 12 & 118 & 130 & $1.870,00$ & $8.586,50$ & $10.456,50$ & $3.512,50$ \\
\hline Galang Batand & 608 & 1.368 & 1.972 & $1.591 .995,22$ & $536.764,97$ & $2.128 .670,69$ & $1.478 .907,22$ \\
\hline Luar Kepri & 1.044 & 2.423 & 3.467 & $3.335 .558,32$ & $1.187 .822,97$ & 4.523.381,29 & $1.838 .261,72$ \\
\hline Pulau Bintan & 317 & 1.745 & 2.062 & $623.237,00$ & $2.141 .471,00$ & $2.764 .708,00$ & $2.510 .672,00$ \\
\hline $\begin{array}{l}\text { Kepulauan } \\
\text { Riau }\end{array}$ & 1.361 & 4.168 & 5.529 & $3.958 .795,32$ & $3.329 .293,27$ & $7.288 .089,29$ & $4.348 .933,72$ \\
\hline
\end{tabular}

Gambar 2. Biaya penyediaan tenaga listrik

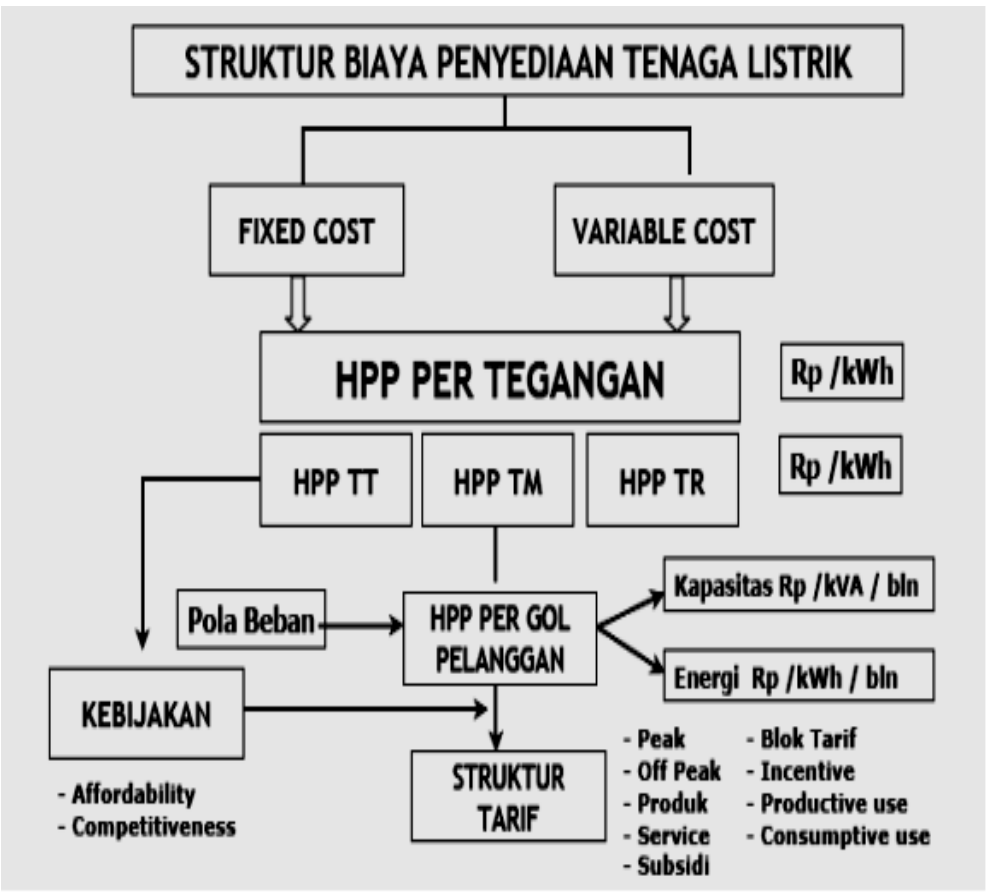

Gambar 3. Bagan struktur biaya penyediaan tenaga listrik

Tanjungpinang merupakan kawasan industri, jadi responden di Kota Tanjungpinang lebih antusias dalam memberikan keterangan tentang daya pembangkit. Dari 12 responden, hanya satu responden yang memiliki daya pembangkit berkapasitas antara $500-1000 \mathrm{kVA}$, dan selebihnya berkapasitas lebih dari $1000 \mathrm{kVA}$, bahkan ada yang sampai $140.915 \mathrm{kVA}$,

Semua responden di Kota Tanjungpinang memberikan data tentang daya pembangkit. Kapasitas daya pembangkit sangat bervariasi, 
yang berkapasitas kurang dari $500 \mathrm{kVA}$ ada $64 \%$, antara $500-1000$ tidak ada, namun yang lebih dari $1000 \mathrm{kVA}$ ada $36 \%$. Dari hasil survey juga dapat dilihat bahwa 19\% responden bergerak di bidang Supermarket, $27 \%$ di bidang industri, dan yang lainnya bergerak di bidang perhotelan, perbankan, perbengkelan dan bandara.

Proses Struktur biaya penyediaan tenaga listrik dapat dikelompokkan atas biaya tetap dan biaya variabel, dengan demikian biaya penyediaan tenaga listrik total berasal dari sebagian tertentu biaya tetap dan sebagian tertentu dari biaya variabel. Biaya tetap merupakan bagian dari biaya total penyediaan tenaga listrik yang tidak terpengaruh (tidak berubah) dengan adanya perubahan dalam kuantitas produksi dalam kisaran yang relevan dalam hal ini jumlah Kwh energi yang diproduksi. Dengan demikian, biaya tetap adalah biaya variabel per unit tetapi konstan dalam kisaran yang relevan. Sedangkan biaya variabel adalah perubahan biaya total dihubungkan dengan setiap perubahan dalam kuantitas Kwh yang diproduksi.

\section{HASIL DAN PEMBAHASAN}

Pembagian daya generator berdasarkan hasil survey di Kota Tanjungpinang disajikan pada Gambar 4. Berdasarkan hasil analisis survey didapatkan empat pokok bahasan diantaranya identifikasi captive power, analisis teknis dan ekonomis, analisis system kelistrikan dengan masuknya captive power, dan kajian potensi pemanfaatan excess power.

Dari beberapa perusahaan yang disurvey di Kota Tanjungpinang, hanya ada satu perusahaan yang bersedia menjual excess power. Perusahaan tersebut bersedia menjual excess power, sebab generator set yang dimiliki perusahaan tersebut cukup berlebih. Dari 5 genset yang ada, hanya 4 genset yang dimanfaatkan. 4 genset tersebut dimanfaatkan sebagai cadangan apabila listrik dari PLN mengalami gangguan. Sehingga terdapat satu sisa genset yang tidak pernah digunakan meskipun PLN mengalami gangguan, sebab 4 genset tersebut sudah cukup untuk memenuhi kebutuhan. Perusahaan tersebut bersedia menjual excess power dari satu genset yang tersisa, dengan syarat PLN bersedia memberikan jaminan proteksi pada genset tersebut dan bersedia menanggung seluruh modifikasi yang sekiranya diperlukan apabila genset tersebut akan dihubungkan ke grid.

Responden yang bersedia menjual Excess Power (EP) hanya 5\% dengan harga Rp.1500/kwh selama 24 jam penuh. Sedangkan perusahaan-perusahaan yang lain, rata-rata tidak bersedia menjual captive power kepada PLN karena genset yang mereka miliki hanya cukup untuk menyuplai kebutuhan mereka sendiri ketika PLN mengalami gangguan. Daya pembangkit yang dimiliki oleh perusahaan-perusahaan tersebut berkapasitas $350-2125 \mathrm{kVA}$. Jarak antara perusahaan 100 - 500 meter darifeeder JTM $20 \mathrm{kV}$ atau SUTT 70/150kV.

Responden menghendaki persyaratan harga jual harus sesuai dengan permintaan responden dan EP yang dijual harus dipakai semua oleh konsumen. harus ada kesepakatan antara pihak perusahaan dengan PLN perihal penggunaan jaringan untuk distribusi EP ke konsumen. Sedangkan kendala yang ada yaitu belum adanya kerjasama antar pihak perusahaan dengan PLN dan harga yang diminati responden masih lebih tinggi daripada harga PLN. Dari informasi beban, dapat tergambar bahwa daya pembangkit yang dimiliki sebenarnya berpotensi menjual EP. Hasil survey kesediaan perusahaan menjual captive power disajikan pada Gambar 5.

\section{KESIMPULAN}

Kesimpulan yang dapat diambil dari PKM PKUK ini, yaitu Tanjungpinang, jumlah daya captive power baik murni maupun cadangan sebesar 4.523 MVA relatif cukup besar dibanding dengan kapasitas daya terpasang PLN sekitar 6.159 MW. Hal ini menunjukkan adanya potensi pengelolaan captive power 


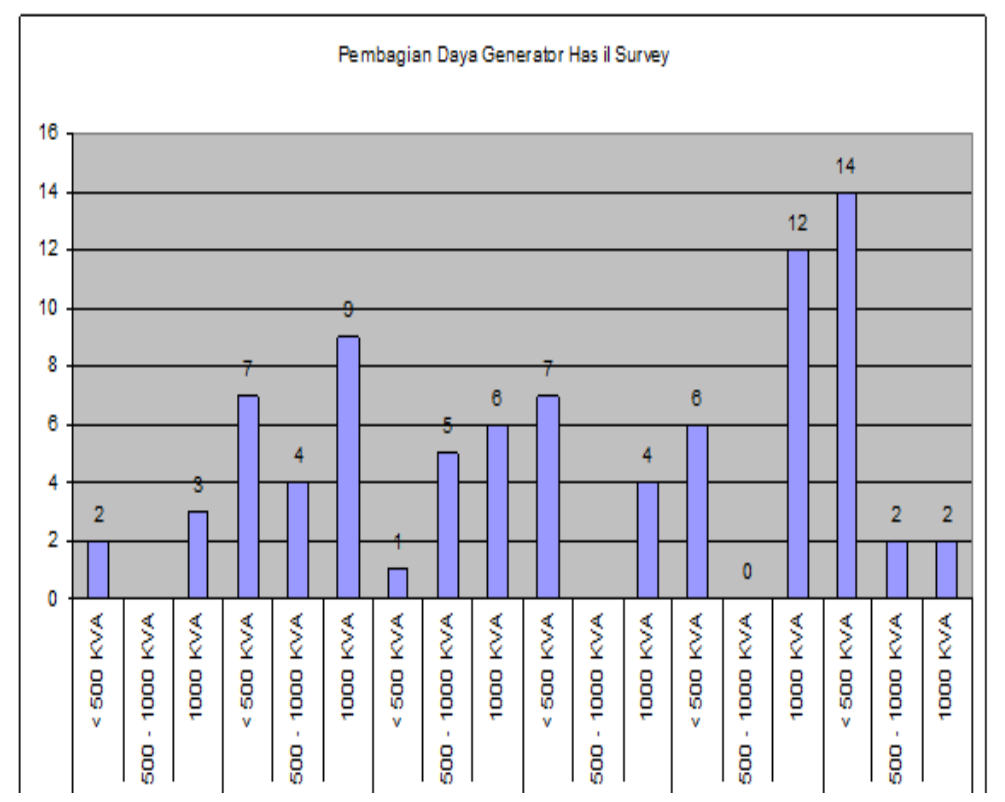

Gambar 4. Daya generator di Kota Tanjungpinang

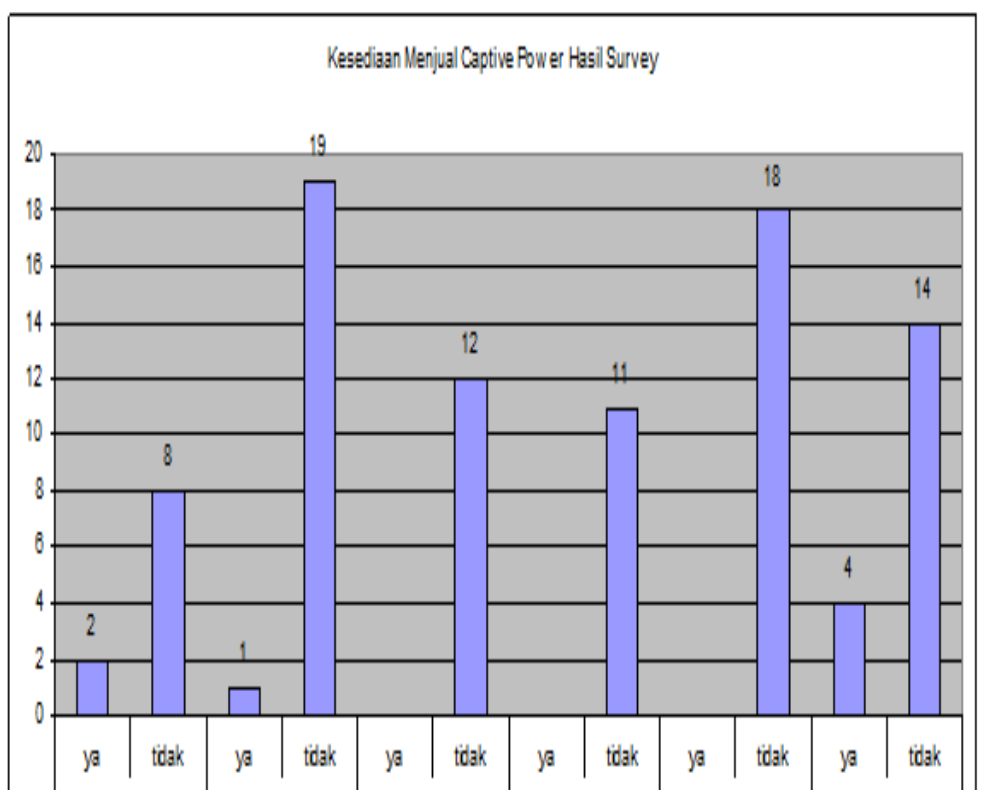

Gambar 5. Kesediaan menjual captive power

untuk dapat diarahkan ke kondisi memiliki excess power; Presentase captive power yang memiliki excess power masih sangat rendah; serta Aksesibilitas informasi captive power di perusahaan masih relatif sulit, tidak seluruh responden dapat memberikan keterangan yang memadai.

\section{DAFTAR PUSTAKA}

Ahmad AS, et. al. 2014. A Review on Application of ANN and SVM for Building electrical energy consumption forcasting. Renewable and Sustainable Energy Reviews. 33 : 102-109.

Council EPA. 2010. Directive 2010/31/EU of the European Parlianment and of the council 19 May, 2010 on the energy performance of buildings. Official Journal of the European Union. 12(003) : 124-146.

Dhirani LL, Newe T, Elfed L, Nizamani S. 2017. Cloud computing and internet of things fusion : cost issues. Eleventh International Conference on Sensing Technology (ICST). 
Mena-Yedra R, Rodriguez F, Castilla MdM, Arahal MR. 2014. A prediction model based on neural networks for the energy consumption of a bioelimatic building. Energy and Building. 82.

Ekonomou L. 2010. Greek long-term energy consumption prediction using artificial neural network. Energy. 35 (2) : 512-517.
Zang P, Wang H. 2012. Fuzzy wavelet neural networks for city electric energy consumption forecasting. Energy Procelia. 17 (B) : 1332-1338.

Yang L, Lam JC, Tsang CL. 2008. Energy performance of building envelopes in different elimate zone in China. Applied Energy. 85 (9) : 800-817. 